\author{
Ya. Suchikova, A. Lazarenko, S. Kovachov, I. Bohdanov
}

\title{
Nanostructures on the ZnSe Surface: Synthesis, Morphological and Photoluminescent Properties
}

\author{
Berdyansk State Pedagogical University Berdyansk, Ukraine, yanasuchikova@gmail.com
}

\begin{abstract}
Nanostructured zinc selenide has been obtained by electrochemical etching with an $\mathrm{H}_{2} \mathrm{SO}_{4}: \mathrm{H}_{2} \mathrm{O}: \mathrm{H}_{2} \mathrm{O}_{5} \mathrm{OH}=$ 4:1:1 solution used as the electrolyte. The experiment has indicated that the surface consists of two phases, namely the upper layer made up of a dense oxide film and a low-sized porous layer underneath, with a pore diameter of $(30-80) \mathrm{nm}$ and a thickness of interporous walls of $(15-50) \mathrm{nm}$. The investigated dependence of surface porosity on the etching time allows us to explain the main stages of the crystal's electrochemical dissolution during anodizing. The experiment has indicated the presence of three main stages, such as the formation of the Gouy and Helmholtz layers at the semiconductor/electrolyte segregation; pore formation at defect and oxide crystallite locations; spontaneous pore formation. The PL spectra of the samples under study have demonstrated three maxima. The emission band at $2.45 \mathrm{eV}$ is attributable to the presence of oxides, the band at $2.78 \mathrm{EV}$ can be accounted for the corresponding excitons while the band at $2.82 \mathrm{eV}$ stems from quantumdimensional effects. Chemical analysis of the samples has also indicated the presence of oxides on the surface of the nanostructure.
\end{abstract}

Key words: porous $\mathrm{ZnSe}$, electrochemical etching, photoluminescence, morphology, nanostructures, electrolyte.

Received 20 Juiy 2021; Accepted 10 October 2021.

\section{Introduction}

The development of modern solid-state electronics devices requires researchers to be on the lookout for new structural materials $[1,2]$. Traditionally, silicon has been the main semiconductor $[3,4]$ with germanium being also frequently used [5, 6]. Nanostructuring of the surface of those semiconductors has led to further progress in semiconductor electronics and has opened up new prospects for the use of single-component semiconductors $[7,8]$. Technologies for the use of binary semiconductors have also become widespread [9, 10]. Semiconductors of the A3B5 group, namely InP [11, 12], GaAs $[13,14]$ and $\mathrm{GaP}[15,16]$ have become the main materials in the laser $[17,18]$ and sensor $[19,20]$ industries. They are also widely used in solar energy [21, 22]. Thus, the paper [23] has evidenced that indium phosphide nanotubes can be efficiently used in photonics due to the low rate of surface recombination. Porous layers of indium phosphide have been suggested as soft substrates for the synthesis of thin nitride films [24]. Semiconductor metal oxides are gaining popularity as well [25, 26]. The paper [27] has been focused on investigating the conditions for the formation of thin $\mathrm{ZnO}$ films for their subsequent use as a photocatalyst. $\mathrm{TiO}_{2}$ [28], $\mathrm{Al}_{2} \mathrm{O}_{3}$ [29], $\mathrm{SiO}_{2}$ [30], etc. are also practiced on a wide scale.

$\mathrm{A}^{2} \mathrm{~B}^{6}$ high bandgap semiconductors draw attention due to their advantages over other groups, including a wide spectral range and high emitted intensity [31, 32]. The above makes it possible to use them as a basis for the manufacture of luminophores [33], solar cells [34], and lasers [35]. The paper [36] is aimed at demonstrating a cost-effective hydrothermal technology for the synthesis of hierarchically three-dimensional (3D) porous $\mathrm{ZnO}$ layers. According to the authors, these structures are promising and future-oriented for the use of gas sensors by improving gas diffusion and mass transfer. Moreover, porous $\mathrm{ZnO}$ has been obtained by evaporation from zinc 
nitrate with ethanol and TEA. Porous ZnSe has been obtained by chemical transport involving iodine [37]. Such structures are promising for the development of metamaterials with a high refractive index [38].

The article dwells on the technology and mechanism for the synthesis of nanostructured layers on the $\mathrm{ZnSe}$ surface as well as the studies of the morphological, chemical and photoluminescent properties of the resulting nanostructures.

\section{Experiment}

For the experiment, we have used Te-doped samples of a single-crystal $n-Z n S e$ stable cubic $(\beta)$ lattice of the zinc blende type with doping density of $10^{18} \mathrm{~cm}^{-3}$, wafer thickness of $1 \mathrm{~mm}$ and the treated surface area of $0.25 \mathrm{~cm}^{2}$. The nanostructures have been formed by conventional electrochemical etching. Before the experiment, the samples have been mechanically and chemically polished and degreased by washing in ethyl alcohol. The experiment has been conducted in a fluoroplastic electrolytic cell with platinum at the cathode. The semiconductor has been immersed in the electrolyte solution perpendicular to the bottom of the cell opposite the second electrode at a distance of $1 \mathrm{~cm}$. The anodizing time has varied from 5 to 20 minutes with the applied voltage of $20 \mathrm{~V} . \mathrm{H}_{2} \mathrm{SO}_{4}$ aqueous-alcoholic solution with $\mathrm{H}_{2} \mathrm{SO}_{4}: \mathrm{H}_{2} \mathrm{O}: \mathrm{C}_{2} \mathrm{H}_{5} \mathrm{OH}=4: 1: 1$ mixture ratio has been used as the electrolyte.

After the experiment, the samples have been dried under a stream of nitrogen and left in the open air for 3 days. The morphological characteristics of the formed nanostructures have been investigated using a Jeol microscope and chemically analyzed by to the EDAX technique. The surface porosity was calculated using the ImageJ program by binarizing the SEM image. We used a Bandpass filter based on Fourier transforms in order to increase the contrast of pore boundaries. The analysis of microimages using the Image J program is detailed in [39]. Surface porosity is defined as the ratio of the area occupied by pores to the total area of the sample in the field of vision of the microscope. The photoluminescence spectra have been recorded using a KSVU-23 spectral setup at room temperature, with a laser of $337 \mathrm{~nm}$ wavelength used as an excitation source.

\section{Empirical Data and Discussion}

Porous ZnSe layers have been obtained under different electrochemical treatment conditions with the structures demonstrating different micro- and macromorphology depending on the applied voltage and etching time. The correlation between the treatment modes, pore size and por-ZnSe porosity still requires a more detailed investigation; however, the dependence of surface porosity on the etching time is already obvious (Fig. 1).

The analysis of Fig. 1 indicates an active pore formation throughout the entire zinc selenide treatment period, starting from $5 \mathrm{~min}$. The $(0-5) \mathrm{min}$ etching interval is defined as the preparatory stage characterized

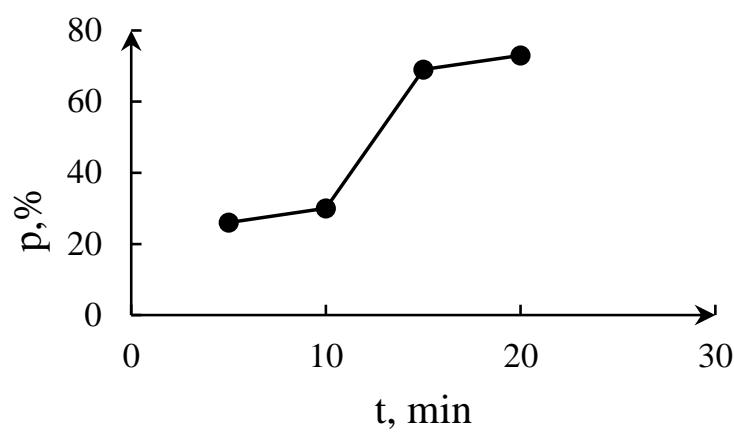

Fig. 1. Diagram of the Dependence of Surface Porosity on the Etching Time.

by the formation of the Gouy and Helmholtz layers as well as adatoms. The $(5-10)$ min etching interval demonstrates a gradual increase in the pore density. This stage is characterized by an increase in the current density indicating the predominance of the breakdown mechanism when atoms are being pulled out from the crystal surface. Etching is observed along the defective areas of the surface throughout this period. In addition, this stage can be characterized by such alternative electrochemical processes as film formation, partial surface polishing, and the like. Pore formation intensifies rapidly in the $(10-15) \mathrm{min}$ etching interval. This indicates the beginning of the spontaneous pore formation with the simultaneous etching of defects and the formation of channels and etching pits. The (15 - 20) min period is marked by a gradual decrease in the rate of pore formation. The electrolyte's seep into the pore bottom is hampered thus slowing down the process of the etching front advancing into the depth of the substrate. The increase in porosity at this stage occurs due to the increase in the lateral pore diameter as well as the etching of the upper film, under which the system is being formed.

Fig. 2 demonstrates a fragment of the por- $\mathrm{ZnSe}$ sample surface subjected to electrochemical treatment for 15 minutes. One can observe an uneven two-layer structure. The top layer is smooth and contains thin long etched channels with the length of these channels varying from 0.5 to $4 \mu \mathrm{m}$. Moreover, this layer is characterized by massive etching pits and crystal cracking from a single center. This indicates that the nuclei of such structures are surface defects and crystal dislocations. A dense porous loose layer is formed in areas located below the smooth layer. The pore diameter ranges from 30 to 80 $\mathrm{nm}$. The size of skeletal crystallites (interpore walls) reaches $(10-50) \mathrm{nm}$.

The uneven etching of the crystal surface, the formation of a continuous film and its gradual etching out by cracking can be explained by the fact that the $\mathrm{A}^{2} \mathrm{~B}^{6}$ semiconductors demonstrate a peculiar stability of their physical properties in general, and of the crystal lattice, in particular [40]. Compared to $\mathrm{A}^{3} \mathrm{~B}^{5}$ compounds, such semiconductors are more resistant to electrochemical dissolution [41]; moreover, choosing selective and dislocation etchants in this case can pose a challenge. For example, $\mathrm{ZnSe}$ is characterized by a significant difference in the effective ionic radii of the 


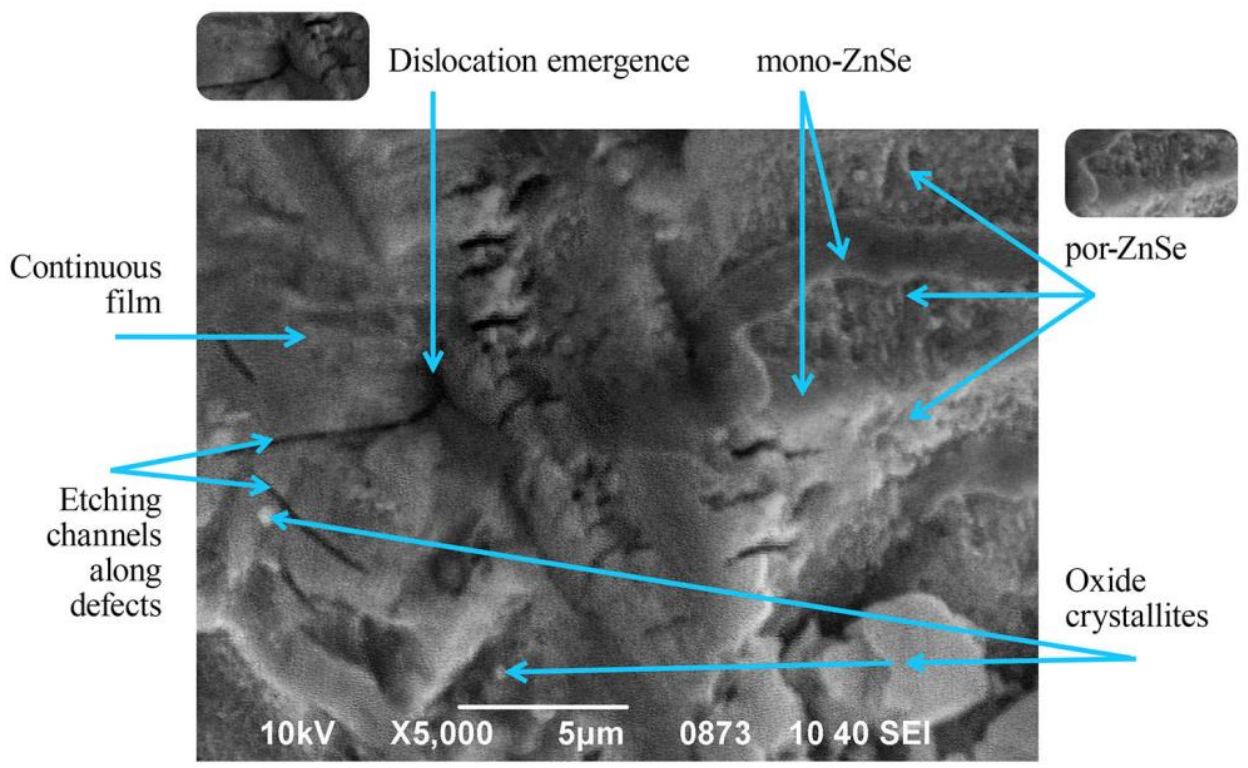

Fig. 2. SEM-Image of the Por-ZnSe Surface Obtained by Electrochemical Etching.

zinc cation and the selenium anion and their distant location within the electrochemical series. This determines the chemical resistance and compound stability. Consequently, etching occurs by two competing mechanisms. On the one hand, etching results in the surface of the crystal being overgrown with a continuous oxide layer; on the other hand, one can observe the formation of a loose porous layer beneath or in oxidefree areas as a result of the etching of the selenium and zinc sublattices. The emergence of such porous layer is not associated with the lattice and surface defects, and is defined as seeding pore formation. Due to the excess voltage, solid films, in turn, begin to crack at defect and dislocation localizations. This leads to the emergence of extended channels, terraces, and etching pits.

Cracking of the crystal with clear radial stripes is particularly interesting. As discussed, the reason for this is crystal lattice defects. As a rule, $\mathrm{ZnSe}$ is characterized by a large number of intrinsic point defects with the predominating vacancies of $\mathrm{Zn}$ and $\mathrm{Se}$ as well as interstitial atoms [42, 43]. Moreover, a high doping level leads to the emergence of dislocations, additional intrinsic defects and a change in the chemical composition due to the isovalent $\mathrm{Se}$ and Te elements.

Most commonly, white spots and crystallites on the surface of nanostructured layers indicate the formation of intrinsic oxides during the electrochemical treatment of the crystal. This statement is confirmed by the chemical analysis of the samples made by the EDAX technique (Table 1). The spectra have been taken at four arbitrary points of the sample fragment.

When analyzing the compositional breakdown of the sample, one can see that the stoichiometry of the sample is shifted towards excess zinc. Primarily, this is explained by the fact that monocrystalline $\mathrm{ZnSe}$ contains more zinc than selenium. Secondly, the selenium sublattices are etched out much faster, with fewer bonds on the crystal surface. The reaction occurring with the predominant etching out of selenium is also evidenced by
Table 1

Component Composition of Por-ZnSe Obtained by the EDAX Technique

\begin{tabular}{|c|c|c|c|}
\hline \multirow{2}{*}{ Spectrum } & \multicolumn{3}{|c|}{ Component } \\
\cline { 2 - 4 } & $O$ & $Z n$ & $S e$ \\
\hline 1 & 14.35 & 60.82 & 24.83 \\
\hline 2 & 8.72 & 61.40 & 29.88 \\
\hline 3 & 3.77 & 57.68 & 38.55 \\
\hline 4 & 23.24 & 58.59 & 18.17 \\
\hline
\end{tabular}

the fact that the electrolyte solution becomes pink when being etched. In addition, we can observe the presence of oxygen on the crystal surface, especially at points 1 and 4 in Fig. 3. This can confirm the hypothesis that light spots and crystallites are localizations of intrinsic oxides formed during the electrochemical etching of the sample. Such oxides can be $\mathrm{ZnO}, \mathrm{ZnSeO}, \mathrm{SeO}$ and the like.

The PL spectrum exhibits an emission band of $2.78 \mathrm{eV}$ close to the band-gap of monocrystalline zinc selenide (Fig. 4). The emergence of this peak can be attributed to excitons [44]. The $2.45 \mathrm{eV}$ emission band has a much lower intensity. It indicates the passivation of the surface with a film containing oxygen. This correlates well with the earlier conclusions about the presence of oxides on the surface of porous zinc selenide. There is also an intense PL band at $2.82 \mathrm{eV}$. This shift is due to quantum size effects.

The change in the energy of the emitting junction is determined by the well-known formula [45]:

$$
\Delta E=\frac{\pi^{2} \hbar^{2}}{2 d^{2}}\left(\frac{1}{m_{n}^{*}}+\frac{1}{m_{p}^{*}}\right)
$$

where $d$ is the size (diameter, section) of nanocrystallites determining the quantum size effect, $m_{n}^{*}, m_{p}^{*}$ is the 


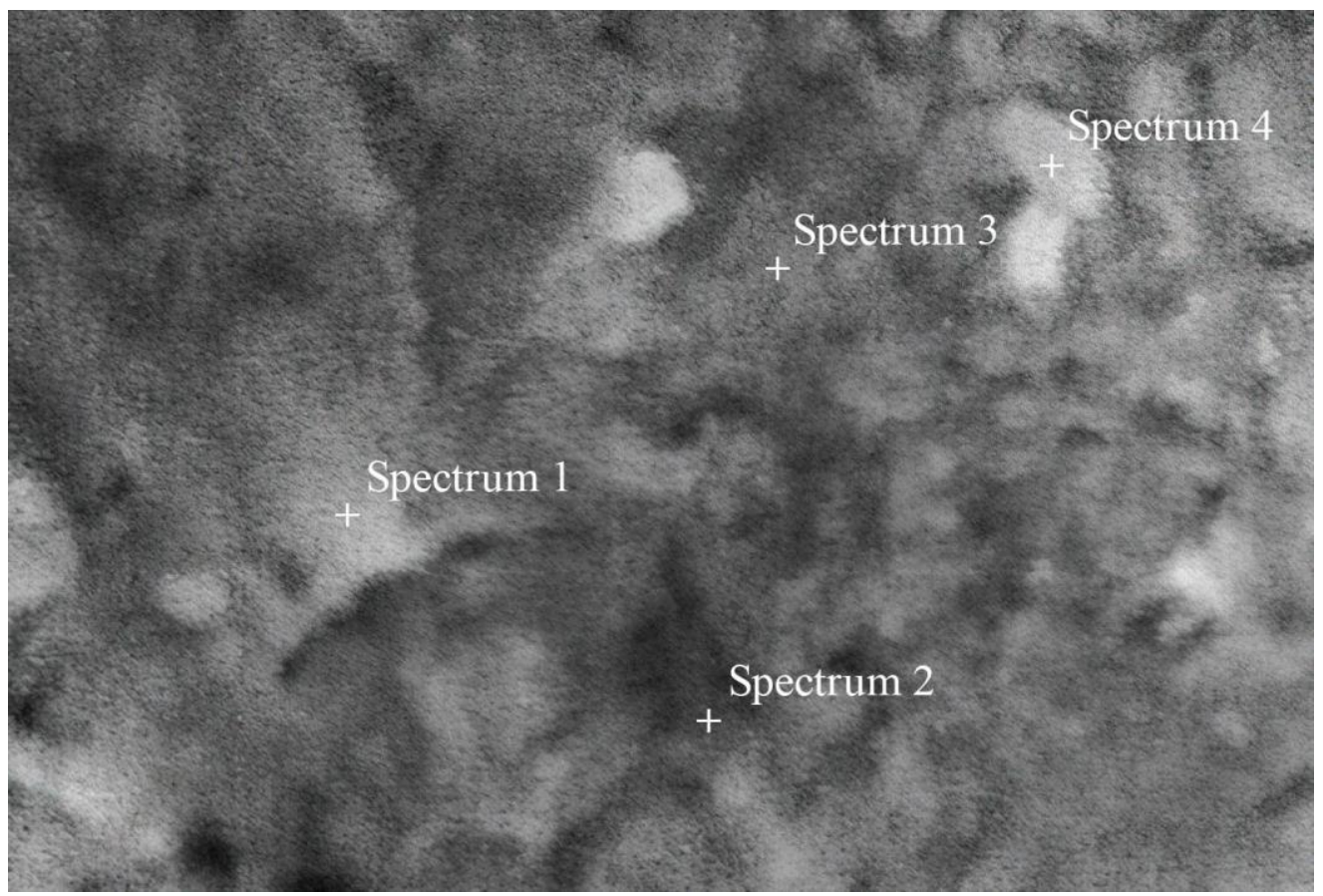

Fig. 3. Fragment of the Por-ZnSe Surface for Analyzing Porous Layer Chemical Composition by the EDAX Technique.

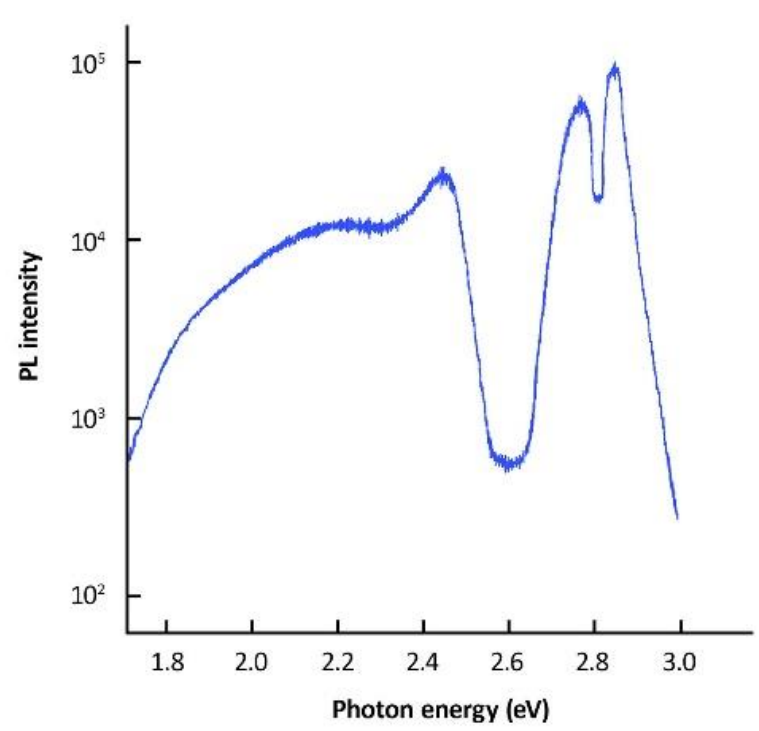

Fig. 4. PL spectra of nanostructured $\mathrm{ZnSe}$.

effective mass of an electron and a hole. With regard to ZnSe: $m_{n}^{*}=0.17 m_{e}, m_{p}^{*}=0.75 m_{e}$.

The given formula (1) allows us to easily estimate the size of nanocrystallites, namely, the "skeletons" (interpore walls), if we assume that the PL spectrum is generated by emission from a set of oscillators [46]. In this case, the largest number of oscillators emits light with energy:

$$
E=E_{\max },
$$

where $E_{\max }$ is the maximum energy of the PL spectrum. The depth of the potential well for these nanoobjects is determined by the formula:

$$
\Delta E=E_{\max }-E_{g},
$$

where $E_{\mathrm{g}}$ is the width of the band-gap.

Relations (1) and (3) make it possible to estimate the size of nanocrystallites. For $E_{\max }=2.82 \mathrm{eV}$, the thickness of the interpore walls will be about $15 \mathrm{~nm}$, which is in good agreement with the data obtained using SEM.

\section{Conclusion}

Thus, we have demonstrated a technique for the synthesis of a porous layer on the surface of a highly doped $\mathrm{ZnSe}(\mathrm{Te})$ by electrochemical etching. It is discovered that nanostructures are not uniform, but consist of two phases, i.e. a porous space and a continuous film. The surface is characterized by a solid film cracking at the defect localizations and consisting mainly of the intrinsic oxides of the semiconductor components. Beneath, there is a low-dimensional highly porous layer leading to a shift of the photoluminescence band through the manifestation of quantum-size effects. The average pore diameter ranges from 30 to $80 \mathrm{~nm}$. The size of the skeletal crystallites has been estimated based on the analysis of SEM micrographs of the sample surface $(15-50 \mathrm{~nm})$ as well as judging from the shift of the por-ZnSe photoluminescence maximum with respect to the mono- $\mathrm{ZnSe}$ photoluminescence maximum $(15 \mathrm{~nm})$. These data are in good agreement.

It is found that the photoluminescence spectrum of nanostructured $\mathrm{ZnSe}$ is characterized by three bands, namely the main one with a maximum of $E_{l}=2.76 \mathrm{eV}$ and additional ones. The band with a maximum at $E_{2}=E_{\max }=2.82 \mathrm{eV}$ is a consequence of the quantum size effect. The band with a maximum of $E_{3}=2.45 \mathrm{eV}$ can be 
explained by the presence of oxygen, which is a component of the semiconductor's own oxides. The presence of the oxide phase is also confirmed by chemical analysis of the components of the sample surface.

The reliability and representativeness of the results are confirmed by various research techniques (SEM, EDAX, PL). However, it should be pointed out that these studies are insufficient to unequivocally identify the mechanisms of the formation of high-quality layers on the surface of the $\mathrm{A}^{2} \mathrm{~B}^{6}$ semiconductors. The conditions for removing the upper oxide layer require further research. Correlation studies of the influence of anodizing conditions on the configuration of a porous surface are also expected to be interesting and promising. The establishment of these regularities will consolidate the status of zinc selenide as a promising photonic material.

\section{Acknowledgment}

The work was carried out as part of the state budget research "Theoretical and methodological foundations of the systemic fundamentalization of the training of future specialists in the field of nanomaterials knowledge for productive professional activity" (state registration number 0121U109426).

Suchikova Ya. - Doctor of Technical Sciences, Associate Professor, Head of the Department of Physics and Methods of Teaching Physics;

Lazarenko A. - Candidate of Physical and Mathematical Sciences, Associate Professor, Associate Professor of Physics and Methods of Teaching Physics;

Kovachov S. - Junior researcher;

Bohdanov I. - Doctor of Pedagogical Sciences, Professor, Rector.

[1] Y.O. Sychikova, I.T. Bogdanov, S.S. Kovachov, Functional Materials 27(1), 29 (2019); https://doi.org/10.15407/fm27.01.29.

[2] S. Vambol, I. Bogdanov, V.Vambol, S. Onishchenko, Eastern-European Journal of Enterprise Technologies 3(5-87), 37 (2017); https://doi.org/10.15587/1729-4061.2017.104039.

[3] V. Petrova-Koch, T. Muschik, A. Kux, B. K. Meyer, F. Koch, V. Lehmann, Applied physics letters 61(8), 943 (1992); https://doi.org/10.1063/1.107736.

[4] Y. Suchikova, Eastern-European Journal of Enterprise Technologies, 6(5), 33 (2016); https://doi.org/10.15587/1729-4061.2016.85848.

[5] A. El-Denglawey, M.M. Makhlouf, M. Dongol, Results in Physics 10, 714 (2018); https://doi.org/10.1016/j.rinp.2018.07.023.

[6] G. Kartopu, A. V. Sapelkin, V. A. Karavanskii, U. Serincan, R. Turan, Journal of Applied Physics 103(11), 113518 (2008); https://doi.org/10.1063/1.2924417.

[7] S. Takagi, R. Zhang, J. Suh, S. H. Kim, M. Yokoyama, K. Nishi, M. Takenaka, Japanese Journal of Applied Physics, 54(6S1), 06FA01 (2015); https://doi.org/10.7567/JJAP.54.06FA01.

[8] G. Niu, G. Capellini, M. A. Schubert, T. Niermann, P. Zaumseil, J. Katzer, T. Schroeder, Scientific reports 6(1), 1 (2016); https://doi.org/10.1038/srep22709.

[9] Y. Suohikova, S. Vambol, V. Vambol, N. Mozaffari, N. Mozaffari, Journal of Achievements in Materials and Manufacturing Engineering 92(1-2), 19 (2019); https://doi.org/10.5604/01.3001.0013.3184.

[10] M. Yazdchi, A. A. Foroughi, S. Talatahari, A. H. Gandomi, Applied Sciences 11(6), 2529 (2021); https://doi.org/10.3390/app11062529.

[11] Y.A. Sychikova, V.V. Kidalov, G.A. Sukach, Journal of Surface Investigation 7(4), 626 (2013); https://doi.org/10.1134/S1027451013030130.

[12] Y.O. Suchikova, Journal of Nano- and Electronic Physics 9(1), 01006 (2017); https://doi.org/10.21272/jnep.9(1).01006.

[13] D.Q. Tran, M.E. Islam, K. Higashimine, M. Akabori, Journal of Crystal Growth 564, 126126 (2021); https://doi.org/10.1016/j.jcrysgro.2021.126126.

[14] S. Vambol, I. Bogdanov, V. Vambol, N. Tsybuliak, Eastern-European Journal of Enterprise Technologies 6(5-90), 22 (2017); https://doi.org/10.15587/1729-4061.2017.118725.

[15] J. Sabataityt, I. Šimkien, A. N. Baranov, R. A. Bendorius, V. Pačebutas, Materials Science and Engineering: C 23(1-2), 43 (2003); https://doi.org/10.1016/S0928-4931(02)00223-0.

[16] S. Vambol, V. Vambol, Y. Suchikova, I. Bogdanov, O. Kondratenko, Journal of Achievements in Materials and Manufacturing Engineering 86(2), 49 (2018); https://doi.org/10.5604/01.3001.0011.8236.

[17] V. Sergentu, D. Esinenco, L. Sirbu, I. Vodä, International Workshop Terahertz and Mid Infrared Radiation: Basic Research and Practical Applications (IEEE, Marmaris, Mugla, Turkey, 2009); https://doi.org/10.1109/TERAMIR.2009.5379611.

[18] V.P. Makhnij, I.I. German, V.M. Sklarchuk, Telecommunications and Radio Engineering 74(16) (2015); https://doi.org/10.1615/TelecomRadEng.v74.i16.60.

[19] A. Salehi, A. Nikfarjam, D. J. Kalantari, Sensors and Actuators B: Chemical 113(1), 419 (2006); https://doi.org/10.1016/j.snb.2005.03.064.

[20] T. Sato, X. Zhang, K. Ito, S. Matsumoto, Y. Kumazaki, IEEE SENSORS (IEEE, Glasgow, Scotland 2016); https://doi.org/10.1109/ICSENS.2016.7808443. 
[21] Y.O. Suchikova, Bogdanov, S.S. Kovachov, Kamensky, N.Y. Panova, Archives of Materials Science and Engineering 101(1), 15 (2020); https://doi.org/10.5604/01.3001.0013.9502.

[22] T. Sato, N. Yoshizawa, T. Hashizume, Thin Solid Films 518(15), 4399 (2010); https://doi.org/10.1016/j.tsf.2010.02.029.

[23] H.J. Joyce, C.J. Docherty, Q. Gao, Tan, M.B. Johnston, Nanotechnology 24(21), 214006 (2013); https://doi.org/10.1088/0957-4484/24/21/214006.

[24] J.A. Suchikova, Journal of Nano- and Electronic Physics 7(3), 03017, 2015.

[25] A. Usseinov, Z. Koishybayeva, A. I. Popov, Latvian Journal of Physics and Technical Sciences 58(2), 3 (2021); https://doi.org/10.2478/lpts-2021-0007.

[26] M. Si, Y. Hu, Z. Lin, X. Sun, A. Charnas, D. Zheng, P. D. Ye, Nano Letters 21(1), 500 (2020); https://doi.org/10.1021/acs.nanolett.0c03967.

[27] A. Di Mauro, M. E. Fragala, V. Privitera, G. Impellizzeri. Materials Science in Semiconductor Processing 69, 44 (2017); https://doi.org/10.1016/j.mssp.2017.03.029.

[28] V. Serga, R. Burve, A. Krumina, M. Romanova, A.I. Popov, Crystals 11(4), 431 (2021); https://doi.org/10.3390/cryst11040431.

[29] E. Shablonin, A. I. Popov, G. Prieditis, E. Vasil'chenko, A. Lushchik, Journal of Nuclear Materials 543, 152600 (2021); https://doi.org/10.1016/j.jnucmat.2020.152600.

[30] R. Balakhayeva, A. Akilbekov, Baimukhanov, A. Dauletbekova, Physica Status Solidi (a), 218(1), 2000231, (2021); https://doi.org/10.1002/pssa.202000231.

[31] O.V. Bogdankevich, M.M. Zverev, A.I. Krasilnikov, A.N. Pechenov, Physica Status Solidi B Basic Research 19(1), K5 (1967); https://doi.org/10.1002/pssb.19670190148.

[32] I.V. Rogozin, Thin Solid Films 517(15), 4318 (2009); https://doi.org/10.1016/j.tsf.2008.12.002.

[33] D. Rehani, S. Bishnoi, M. Saxena, D. Haranath, V. Gupta, S. N. Sharma, Journal of Physics and Chemistry of Solids 143, 109460 (2020); https://doi.org/10.1016/j.jpcs.2020.109460.

[34] G. Khrypunov, S. Vambol, N. Deyneko, Eastern-European Journal of Enterprise Technologies 6(5), 12 (2016); https://doi.org/10.15587/1729-4061.2016.85617.

[35] A.S. Nasibov, V.G. Bagramov, K.V. Berezhnoi, P.V. Shapkin, Bulletin of the Lebedev Physics Institute 40(4), 97 (2013); https://doi.org/10.3103/S1068335613040040.

[36] K.S. Babu, A.R. Reddy, C. Sujatha, K.V. Reddy, A.N. Mallika, Journal of Advanced Ceramics 2(3), 260 (2013); https://doi.org/10.1007/s40145-013-0069-6.

[37] E. Monaico, I.M. Tiginyanu, V.P. Sirkeli, Semiconductor science and technology 22(10), 1115 (2007); https://doi.org/10.1088/0268-1242/22/10/007.

[38] E. Monaico, P. Tighineanu, I. Tiginyanu, Physica Status Solidi 3(4), $97 \quad$ (2009); https://doi.org/10.1002/pssr.200903026.

[39] Y. Suchikova, I. Bogdanov, S. Kovachov, N. Tsybuliak, N. Panova, Nanosistemi, Nanomateriali, Nanotehnologii 18(4), 875 (2020); https://doi.org/10.15407/nnn.18.04.875.

[40] T.V. L'vova, I.V. Sedova, Ulin, S.V. Ivanov, Vacuum 57(2), 163 (2000); https://doi.org/10.1016/S0042207X(00)00114-7.

[41] V.P. Ulin, S.G. Konnikov, Semiconductors 41(7), 832 (2007); https://doi.org/10.1134/S1063782607070111.

[42] K.Yoshino, H. Mikami, K. Imai, T. Ikari, Physica B: Condensed Matter. 302, 299 (2001); https://doi.org/10.1016/S0921-4526(01)00444-6.

[43] M. Heuken, J.Söllner, F. E. G. Guimaraes, K. Marquardt, K. Heime, Journal of crystal growth 117(1-4), 336 (1992); https://doi.org/10.1016/0022-0248(92)90771-A.

[44] R. Baltramiejūnas, V.D. Ryzhikov, V. Stepankevičius, Journal of luminescence 52(1-4), 71 (1992); https://doi.org/10.1016/0022-2313(92)90234-Z.

[45] V.M. Asnin, N.S. Averkiev, A.B. Churilov, I.I. Markov, Solid state communications 87(9), 817 (1993); https://doi.org/10.1016/0038-1098(93)90421-I.

[46] N.S. Averkiev, L.P. Kazakova, É.A. Lebedev, N.N. Smirnova, Semiconductors 34(6), 732 (2000); https://doi.org/10.1134/1.1188063. 


\author{
Я.О. Сичікова, А.С. Лазаренко, С.С. Ковачов, І.Т. Богданов
}

\title{
Наноструктури на поверхні ZnSe: синтез, морфологічні та фотолюмінісцентні характеристики
}

\author{
Бердянський державний педагогічний університет, Бердянськ, Україна, уапаsисhikova@ gmail.com
}

Наноструктурований селенід цинку було отримано методом електрохімічного травлення. у якості електроліту було використано розчин $\mathrm{H}_{2} \mathrm{SO}_{4}: \mathrm{H}_{2} \mathrm{O}: \mathrm{H}_{2} \mathrm{O}_{5} \mathrm{OH}=4: 1: 1$. Встановлено, що поверхня характеризується наявністю двох фаз: верхній шар складається 3 щільної оксидної плівки, під ним низькорозмірний поруватий шар 3 діаметром пор (30 - 80) нм та товщиною міжпорових простінок (15 50) нм. Досліджено залежність поверхневої поруватості від часу травлення, що дозволило пояснити основні етапи електрохімічного розчинення кристалу під час анодування. Показано наявність трьох основних етапів: формування шарів Гуї та Гельмгольцу на межі розділу напівпровідик/електроліт; пороутворення в місцях локалізації дефектів та формування оксидних кристалітів; спонтанне пороутворення. Спектри ФЛ досліджуваних зразків демонструють три максимуми. Полоса випромінювання при 2,45 еВ зумовлена наявністю оксидів, за полосу 2,78 ЕВ відповідні екситони, полоса при 2,82 еВ зумовлюється проявом квантово-розмірних ефектів. Хімічний аналіз зразків також показав наявність оксидів на поверхні наноструктури.

Ключові слова: поруватий $\mathrm{ZnSe}$, електрохімічне травлення, фотолюмінесценція, морфологія, наноструктури, електроліт. 